\title{
Access to healthcare as an important moderating variable for understanding geography of immunity levels for COVID-19 - preliminary insights from Poland
}

\author{
Andrzej Jarynowski \\ Institute for Veterinary Epidemiology and Biostatistics, Freie Universität Berlin, \\ Germany \\ Interdisciplinary Research Institute, Wroclaw, Poland \\ Aidmed, Gdańsk, Poland \\ ajarynowski@fu-berlin.de \\ Vitaly Belik \\ Institute for Veterinary Epidemiology and Biostatistics, Freie Universität Berlin, \\ Germany \\ vitaly.berlik@fu-berlin.de
}

\begin{abstract}
Background. Underascertainment of COVID-19 burden and uncertainty in estimation of immunity levels is a known and common phenomenon in infectious diseases. We tested to what extent healthcare access (HCA) related supply/demand interfered with registered data on COVID-19 from Poland.

Material and methods. We have run a multiple linear regressions model with interactions to explain geographical variability in seroprevalence, hospitalization (on voivodeship -NUTS-2level) and current (beginning of the 4th wave -15.09-21.11.2021) case notifications/crude mortality (on poviats -old NUTS-4- level) taking vaccination coverage and cumulative case notifications till so called 3rd wave as predictor variables and supply/demand (HCA) as moderating variables.

Results. HCA with interacting terms (mainly demand) explained to the great extent the variance of current incidence and most variance in case of current mortality. HCA (mainly supply) is significantly moderating cumulative case notifications till the 3rd wave explaining the variance across seroprevalence.

Conclusions. Seeking causal relations between vaccination or infection gained immunity level and current infection dynamics could be misleading without understanding socioepidemiological context such as the moderating role of HCA (sensu lato). After quantification, HCA could be incorporated into epidemiological models for better prediction of real disease burden.
\end{abstract}

Keywords: healthcare access, health inequalities, COVID-19, statistical modelling, immunity level, quasi-causal diagrams 
medRxiv preprint doi: https://doi.org/10.1101/2021.12.08.21267167; this version posted December 9, 2021 . The copyright holder for this preprint (which was not certified by peer review) is the author/funder, who has granted medRxiv a license to display the preprint in

All rights reserved. No reuse allowed without permission.

\section{Background.}

Knowing immunity levels is important for proper prediction of the COVID-19 dynamics for a given region. Researchers proposed multiple methods and models combining natural immunity possibly acquired after infection with induced immunity by various vaccines taking into account their interactions as well as various immunity waning schema [1,2]. We do know quite well how various vaccines are waning efficacy [3] against symptomatic infections (controlled for covariates such as seasonality or virus variants), however post-infection immunity is much more difficult to assess [4]. Seroprevalence studies can be also used to estimate immunity levels, previously having been heavily used attempting to estimate IFR (Infection fatality rate $[5,6]$ ).

From epidemiological practice, we already know that registered disease case notifications are not covering the real burden of infections to the same extent in various geographical locations due to socio-economic-medical inequalities [7]. Thus, healthcare access (HCA) has been already identified as a possible factor influencing measurable COVID-19 epidemic indexes and explaining intra-country variation [8-11]. For example, more resource-rich regions were able to organize both testing and treating capacities [12] and vaccination campaigns [13] in a faster and more inclusive way, whereas resource-poor regions were much more selective in the pandemic healthcare services delivery.

Surprisingly, HCA was not taken into consideration in infection dynamics modelling practice to much extent yet [11]. While immunity is gained and lost at the individual level, immunity level often is tried to be quantified at a population level, for instance, by accounting for biased measures such as estimates of undiagnosed cases or eliciting seroprevalence surveys. Wrong estimates of COVID-19 immunity levels varying over time and regions makes predictions challenging and significantly reduces predictive power. Thus, forecasts results are often far from reality, as was the case in Poland between June-September 2021 [14]. Moreover, recently some ecological studies are suggesting a weak or no link between vaccination coverage and current epidemic dynamics in the general populations, which has gained a lot of controversy and our observations puts a new light on it [15].

\section{Material and methods.}

We show on the example of Poland that omitting HCA confounding factors could lead to misinterpretation in understanding current epidemic dynamics due to biased estimation of immunity levels.

Data obtained from Polish registries on 16 voivodeships (NUTS-2) and 380 poviats (old NUTS4):

- Cumulative No. cases per capita (cumulative cases): The cumulative numbers of COVID-19 notifications till the so-called $3^{\text {rd }}$ wave of epidemic $(04.03 .2020$ 15.06.2021) for poviat or voivodeship [16] divided by its population size.

- Healthcare Access - Supply (supply HCA): The number of physicians working in health care per 10,000 inhabitants as an indicator of the supply HCA for poviat or voivodeship [17]. This is a good proxy for capacity and accessibility of healthcare services (public and private).

- Healthcare Access - Demand (demand HCA): The number of consultations in primary care provided in 2019 for poviat or voivodeship divided by its population size 
medRxiv preprint doi: https://doi.org/10.1101/2021.12.08.21267167; this version posted December 9, 2021 . The copyright holder for this preprint (which was not certified by peer review) is the author/funder, who has granted medRxiv a license to display the preprint in

All rights reserved. No reuse allowed without permission.

as an indicator of demand HCA [17]. Pearson correlation on demand HCA in 2019 and 2020 is 0.998 [13], so no significant regional changes have been observed in the demand for HCA due to the pandemic. Demand HCA is a complicated conglomerate of attitudes towards healthcare (i.e. level of trust in the effectiveness of offered treatment by public healthcare), perception of accessibility (i.e. how easily one can reach healthcare facilities), burden of disease (i.e. elderly and inferior health populations seek healthcare more often) and others (i.e. constrains and limits provided by National Health Fund).

- Fraction of vaccinated: Percentage of vaccinated with at least one dose for poviat or voivodeship (at the end of $3^{\text {rd }}$ wave as of 15.06.2021) for all age groups [18]. Vaccination coverage gives us a proxy of proportions of population which gain postvaccination immunity before the so-called $4^{\text {th }}$ wave.

- Normalized incidence Sep/Oct'21 (Incidence): 2-week incidence of COVID-19 notifications (21.09-04.10.2021) during the beginning of the so-called $4^{\text {th }}$ epidemic wave for a poviat [16].

- Normalized deaths Sep/Nov'21 (deaths): Crude mortality rate - Cumulative number of COVID-19 death cases (15.09-21.11.2021) during the so-called $4^{\text {th }}$ epidemic wave per poviat divided by its population size [19].

- Normalized Hospitalizations (hospitalizations): Number of occupied hospital beds (14.10.2021) at the beginning of the so-called $4^{\text {th }}$ epidemic wave per voivodeship divided by its population size [20].

- Seroprevalence - Obser-Co: The fraction of seroconverted [21] per voivodeship in a random (by design) sample as a proxy for immunity level collected during 29.0314.05.2021. As this was the end of the 3rd epidemic wave, as well as the vaccination roll-out was at the beginning, this variable is a good proxy of post-infection acquired immunity.

The dynamics of SARS-CoV-2 spreading vary across the spatial clusters [12] and initial conditions as number of index cases and immunity levels could lead to different phases at the beginning of each wave. Thus, supply/demand HCA are assumed to be moderating variables that affect the relationship between independent (vaccine or post-infection immunity at the end of $3^{\text {rd }}$ wave) and dependent variables (seroprevalence and the $4^{\text {th }}$ wave outbreak dynamics indexes). Multiple linear regressions were proposed in 4 equations $n \in\{1,2,3,4\}$ with 4 predictors consist of $i \in\{1,2\}$ independent and $i \in\{3,4\}$ moderating variables:

$$
Y_{n}(z)=\alpha^{n}+\sum_{i}^{4} \alpha_{i}{ }^{n} X_{i}(z)+\sum_{i \neq j} \alpha_{i j}{ }^{n} X_{i}(z) X_{j}(z)
$$

Where Generally: $Y_{n}$ are dependent variables; $X_{1}$ and $X_{2}$ are independent variables; $X_{3}$ and $X_{4}$ are moderating variables, $X_{i} X_{j}$ are 2- way interactions terms among predictors.

Where Specifically: $Y_{1}-$ Seroprevalence - Obser-Co; $Y_{2}$ - Normalized Hospitalizations; $Y_{3}-$ Normalized incidence Sep/Oct'21; $Y_{4}$ - Normalized deaths Sep/Nov'21; $z$ is one of 18 voivodships for $Y_{1}$ and $Y_{2}$ or one of 380 poviats for $Y_{3}$ and $Y_{4} ; X_{1}-$ Cumulative No. cases per capita (independent variable); $\mathrm{X}_{2}$ - Fraction of vaccinated (independent variable); $\mathrm{X}_{3}-$ Healthcare Access - Supply/supply HCA (moderating variable); $\mathrm{X}_{4}$ - Healthcare Access Demand/demand HCA (moderating variable); $\alpha$ are intercepts (without subscript indexes) and fitted parameters (with subscript indexes). 
medRxiv preprint doi: https://doi.org/10.1101/2021.12.08.21267167; this version posted December 9,2021 . The copyright holder for this preprint (which was not certified by peer review) is the author/funder, who has granted medRxiv a license to display the preprint in perpetuity.

All rights reserved. No reuse allowed without permission.

Flow of explained variance of each dependent $Y_{n}$ variable (in \%) by predictors $X_{i}$ and interactions among them is drawn on diagram. As a remark, model does not recognize independent or moderating variables, so presentation of directionality of interactions terms on diagrams is a priori convention only.

\section{Results.}

In a series of diagrams, we depict the explained share of variance for selected dependent variables of interest as calculated by multiple regression. The following predictor variables were used: vaccination coverage, cumulative case notifications, moderating terms supply/demand HCA as well as 2-way interactions among them (Tab. 1, Fig. 1-4).

Table 1) Procent of explained variance (\%Exp) and significance level ( $p-V)$ for given selection of predictors with interactions as independent variables (blue) or moderating variables (orange).

\begin{tabular}{|c|c|c|c|c|c|c|c|c|}
\hline independent variable & Seroprev & valence & Hospital & lizations & Inciden & $\mathrm{ce}^{*}$ & Deaths & \\
\hline predictor & $p-V$ & $\% \operatorname{Exp}$ & $p-V$ & $\% \operatorname{Exp}$ & $p-V$ & $\% \operatorname{Exp}$ & $p-V$ & $\% \operatorname{Exp}$ \\
\hline cumulative cases & 0.129 & 26 & 0.022 & 17 & 0.480 & 0 & 0.112 & 1 \\
\hline fraction of vaccinated & 0.840 & 0 & 0.017 & 20 & 0.129 & 0 & $\mid<0.001$ & 9 \\
\hline supply HCA & 0.889 & 0 & 0.022 & 17 & $\mid<0.001$ & 3 & 0.375 & 0 \\
\hline demand HCA & 0.543 & 3 & 0.191 & 4 & $\mid<0.001$ & 15 & $\mid<0.001$ & 13 \\
\hline cumulative cases: supply HCA & 0.330 & 9 & 0.719 & 0 & 0.006 & 1 & 0.172 & 0 \\
\hline cumulative cases: demand HCA & 0.976 & 0 & 0.564 & 1 & 0.594 & 0 & 0.875 & 0 \\
\hline cumulative cases: fraction of vaccinated & 0.900 & 0 & 0.027 & 15 & 0.003 & 3 & 0.012 & 1 \\
\hline demand HCA: fraction of vaccinated & 0.611 & 2 & 0.549 & 1 & 0.016 & 1 & 0.007 & 1 \\
\hline supply HCA: fraction of vaccinated & 0.266 & 12 & 0.038 & 12 & 0.461 & 0 & 0.364 & 0 \\
\hline supply HCA: demand HCA & 0.393 & 7 & 0.118 & 6 & 0.068 & 1 & 0.336 & 0 \\
\hline Residuals & & 39 & & 8 & & 77 & & 75 \\
\hline
\end{tabular}

* Incidence is sensitive to quadratic as well $3^{\text {rd }}$ way interaction terms, thus it will need further stability analysis

Models presented in Table 1 were not selected according statistical criteria, thus there could be other models base on the same sate of predicting variables with better fit. However, these simple regressions allow us to draw attention which variables and which interactions need further investigation. More variance is explained for hospitalizations (82\%) than seroprevalence $(61 \%)$ on voivodship level. More variance is explained for deaths $(25 \%)$ than incidence $(23 \%)$ on poviat level. 


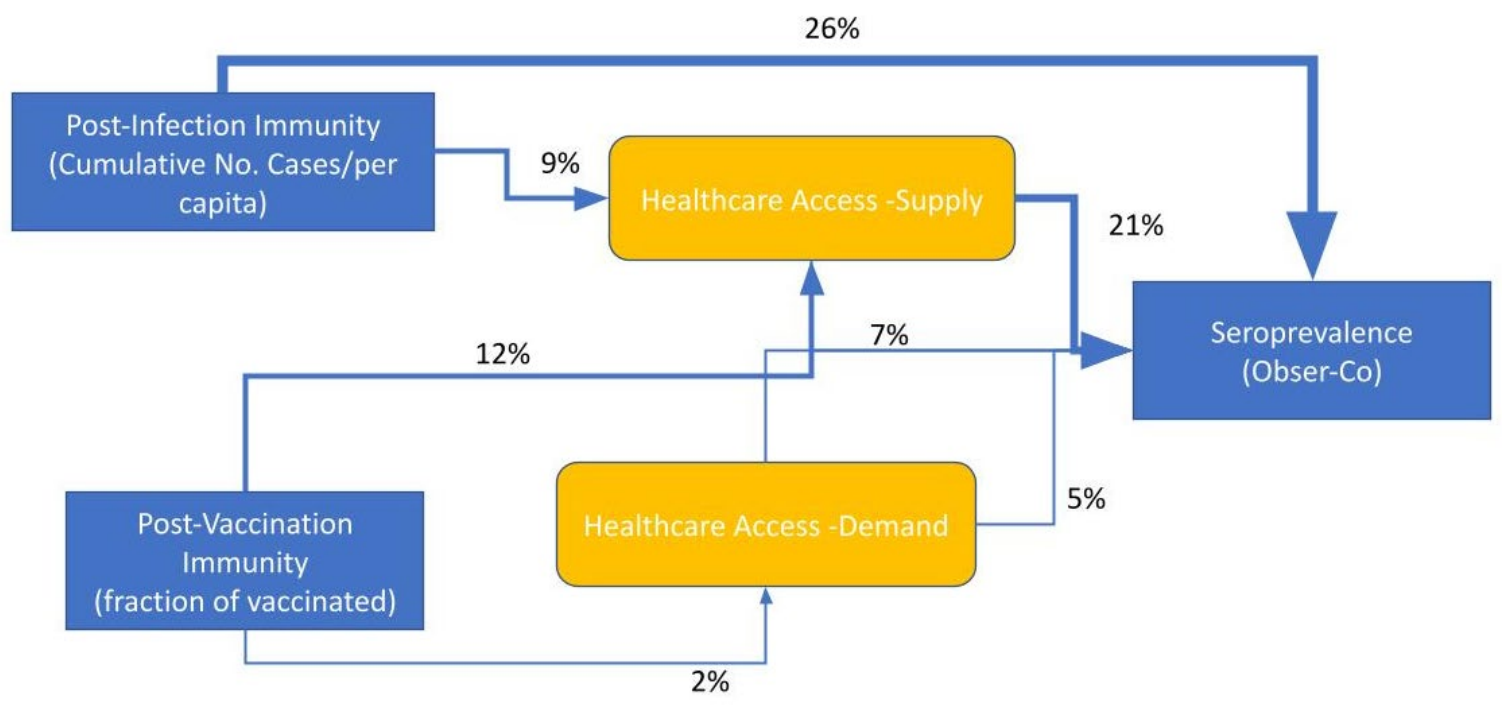

Figure. 1) Explained variance of seroprevalence at the end of $3^{\text {rd }}$ wave - immunity level estimation from Obser-Co [21] on voivodeship level.

HCA (mainly supply) is significantly influencing seroprevalence survey results (Fig. 1), and $12 \%$ of variance is explained by the interaction between cumulative cases notifications and supply HCA. Most of the variance in seroprevalence is explained by cumulative cases notifications (vaccination was in a very early stage at the time of seroprevalence survey).

$17 \%$

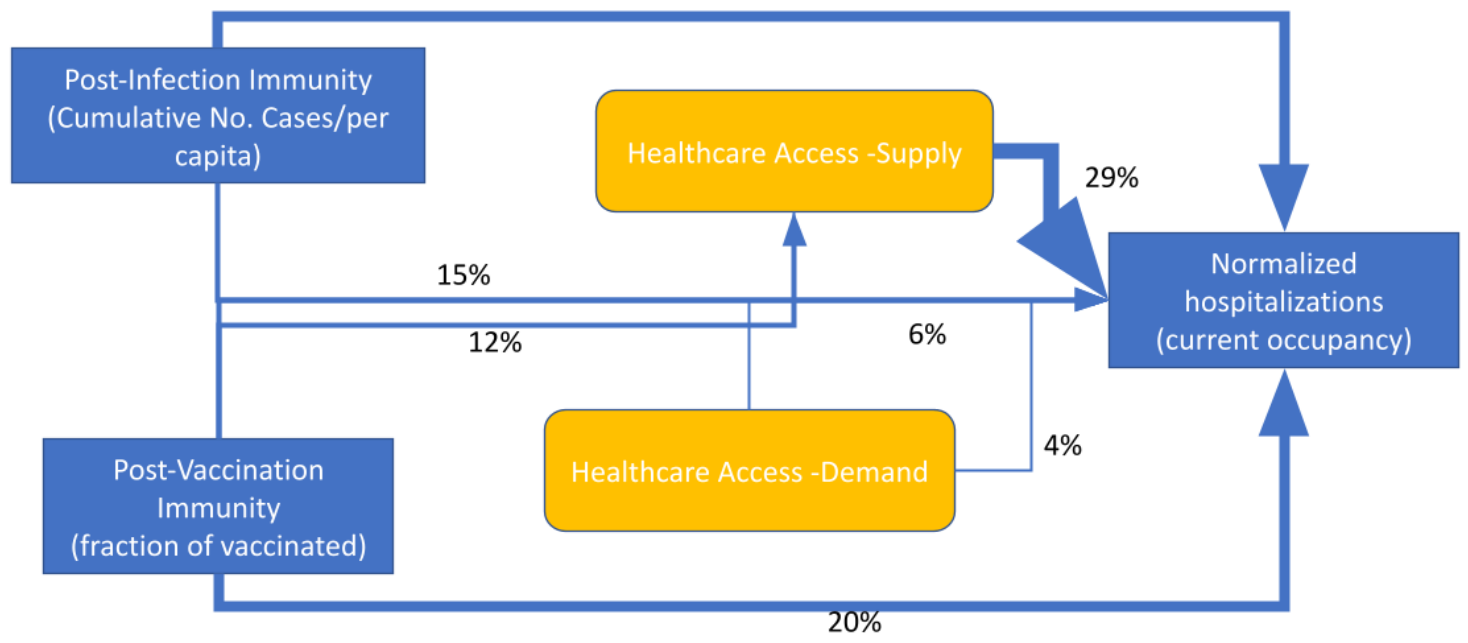

Figure. 2) Explained variance of hospitalizations during the $4^{\text {th }}$ wave on voivodeship level.

Hospitalizations seem to be well predicted by vaccination coverage and cumulative cases notifications (52\% of variance considering also the interaction between them). HCA (mainly supply) is influencing hospitalization (Fig. 2), but $12 \%$ of variance is explained by interaction between vaccination coverage and supply HCA. 
medRxiv preprint doi: https://doi.org/10.1101/2021.12.08.21267167; this version posted December 9, 2021. The copyright holder for this preprint (which was not certified by peer review) is the author/funder, who has granted medRxiv a license to display the preprint in perpetuity.

All rights reserved. No reuse allowed without permission.

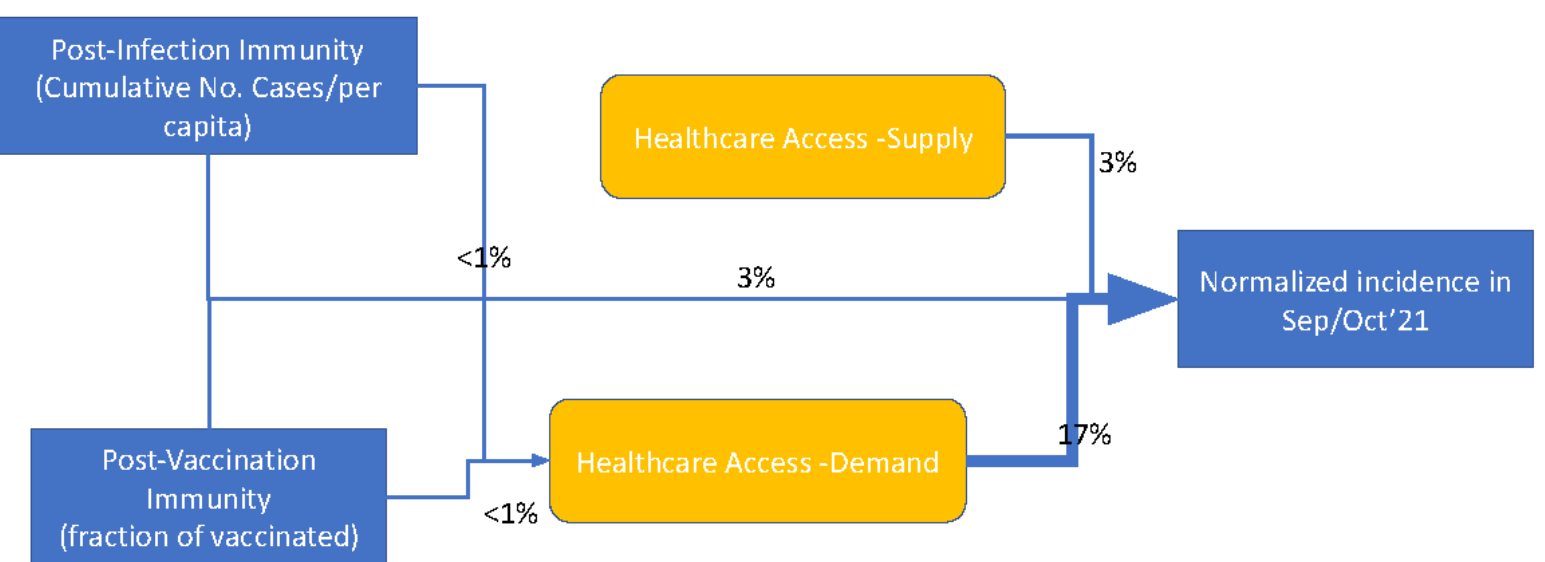

Figure. 3) Explained variance of normalized case notifications (14-days incidence) during the $4^{\text {th }}$ wave on poviat level.

HCA (mainly demand) is extremely important (Fig. 3, 4) to predict current infections dynamic (incidence and mortality). This is worth to stress that direct links between vaccination coverage as well as cumulative case notifications with current incidence are statistically negligible (only interactions with these terms have some impact).

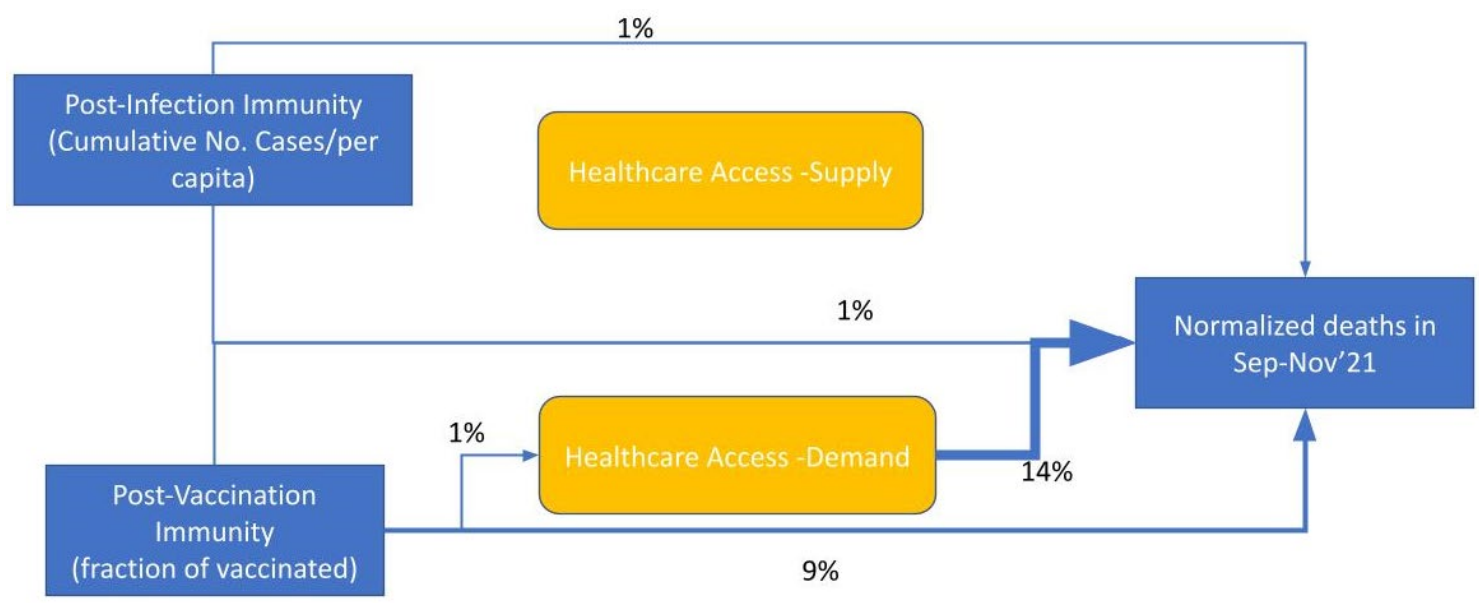

Figure. 4) Explained variance of crude mortality rate during the $4^{\text {th }}$ wave on poviat level.

Crude mortality rate (Fig. 4) in comparison to incidence (Fig. 3) during the beginning of the 4th wave is less prone to the confounding effect of HCA. We can see a significant link (Fig. 4) between vaccination coverage and crude mortality rate due to COVID-19.

\section{Conclusions.}

There are multiple possible mechanisms explaining mediating role of HCA (however causal statements cannot be defined as probably both explaining and explanatory variable seems to depend on HCA):

- In regions with high availability of healthcare workers (supply HCA) patients are more likely to be sampled as seroconverted (Fig. 1), have higher chance to find a hospital bed (Fig. 2), as well as chance of being tested (and get positive result) increases a little (Fig. 3).

- Case notifications as well as in some extent crude mortality (Fig. 3, 4) are highly correlated with the way how patients are likely to use the public healthcare system 
medRxiv preprint doi: https://doi.org/10.1101/2021.12.08.21267167; this version posted December 9, 2021 . The copyright holder for this preprint (which was not certified by peer review) is the author/funder, who has granted medRxiv a license to display the preprint in

All rights reserved. No reuse allowed without permission.

(demand $\mathrm{HCA}$ ), thus in regions with low demand HCA real number of infections seems to be underestimated by documented case notifications to a higher extent than in places with high demand HCA.

Concluding each epidemiological index is more or less confounded by HCA in a different way:

- Seroprevalence surveys and hospitalizations by supply HCA.

- Documented case notifications and crude mortality rates by demand HCA.

Recent suggestion of ECDC [22] and WHO [23] to put more emphasis on hospitalizations/mortality rather than laboratory confirmed cases in understanding the burden of disease is supported by our findings too. Moreover, the lack of or even slightly positive correlations between current incidence and vaccination rates by regions has been confirmed in our study to be significantly confounded by HCA. As this argument is often used by antivaxx movement, it is worth to mention that causal relation cannot be claimed with the observed moderating role of HCA. Thus, vaccination is not only averting hospitalization [20] or death tolls [24] in Poland (Fig. 2, 4), but also probably reduced transmission probability, although it may be partially masked by inequalities in HCA (Fig. 3). Moderating role of HCA could be changing in time; however, this simple analysis suggests that including HCA indexes into models of disease dynamics could increase their long-term predictive power as for instance for short term prediction meteorological condition could be useful [25].

This study is only an exploratory, so-called "zero" approach to illustrate the mediating phenomenon of HCA and has multiple limitations because vaccination coverage, cumulative case notifications, seroprevalence and current outbreak dynamics have been taken for different time periods. Due to availability of explained variables on different levels (voivodeship or poviat) model comparison should be done with caution. Other possible interfering variables were not taken into consideration (as socio-economic-demographic picture of the population). We regret that data gathered by state is not provided in an easy to analyse format [26] and massive manual work is needed for data preparation. The most important variable hospitalization - is not available on poviat level (old NUTS-4). We suggest that the number of hospitalized patients originating from a given region (poviat) could be a very important epidemiological index. Further causal modelling using a longitudinal approach is required to support our preliminary observations. These results are specific to the Polish population / healthcare system and the role of the access to healthcare could be different in other settings.

Acknowledgment

Data, scripts in $R$ and additional diagnostics are available on https://github.com/ajarynowski/Healtcare Access COVID. We thank Monika Wójta-Kempa, Magdalena Rosińska, Kamil Rakocy and Members of Polish Vaccinological Society for consultations. Study was partially supported by DFG (German Research Foundation, project number 458528774).

\section{References}

1. Shearer, F. Incorporating vaccine and exposure-acquired immunity into COVID-19 situational assessment [Internet]. 2021. Available from: http://www.fields.utoronto.ca/activities/21-22/modelling-immunity

2. Glasser, J. Calculating quantities needed for transmission modeling from large-scale serological surveys of antibodies to SARS-CoV-2 in the United States. [Internet]. 2021. 
medRxiv preprint doi: https://doi.org/10.1101/2021.12.08.21267167; this version posted December 9, 2021 . The copyright holder for this preprint (which was not certified by peer review) is the author/funder, who has granted medRxiv a license to display the preprint in perpetuity.

All rights reserved. No reuse allowed without permission.

Available from: http://www.fields.utoronto.ca/activities/21-22/modelling-immunity

3. Nordström P, Ballin M, Nordström A. Effectiveness of Covid-19 Vaccination Against

Risk of Symptomatic Infection, Hospitalization, and Death Up to 9 Months: A Swedish

Total-Population Cohort Study. SSRN Electron J [Internet]. 2021; Available from:

https://www.ssrn.com/abstract $=3949410$

4. CDC. SARS-CoV-2 Infection-induced and Vaccine-induced Immunity [Internet]. 2021.

(Science Brief). Available from: https://www.cdc.gov/coronavirus/2019-

ncov/science/science-briefs/vaccine-induced-immunity.html

5. Ioannidis JPA. Reconciling estimates of global spread and infection fatality rates of COVID-19: An overview of systematic evaluations. Eur J Clin Invest [Internet]. 2021 May;51(5). Available from: https://onlinelibrary.wiley.com/doi/10.1111/eci.13554

6. Meyerowitz-Katz G, Merone L. A systematic review and meta-analysis of published research data on COVID-19 infection fatality rates. Int J Infect Dis. 2020 Dec;101:13848.

7. WHO. Handbook on health inequality monitoring: with a special focus on low- and middle-income countries. :126.

8. Sun Y, Hu X, Xie J. Spatial inequalities of COVID-19 mortality rate in relation to socioeconomic and environmental factors across England. Sci Total Environ. 2021 Mar;758:143595.

9. Dahal S, Luo R, Swahn MH, Chowell G. Geospatial Variability in Excess Death Rates during the COVID-19 Pandemic in Mexico: Examining Socio Demographic and Population Health Characteristics [Internet]. Epidemiology; 2021 Aug. Available from: http://medrxiv.org/lookup/doi/10.1101/2021.08.11.21261930

10. Andersen LM, Harden SR, Sugg MM, Runkle JD, Lundquist TE. Analyzing the spatial determinants of local Covid-19 transmission in the United States. Sci Total Environ. $2021 \mathrm{Feb} ; 754: 142396$.

11. Ayoub HH, Mumtaz GR, Seedat S, Makhoul M, Chemaitelly H, Abu-Raddad LJ. Estimates of global SARS-CoV-2 infection exposure, infection morbidity, and infection mortality rates in 2020. Glob Epidemiol. 2021 Nov;3:100068.

12. Jarynowski A, Wójta-Kempa M, Krzowski Ł, Belik, Vitaly. An attempt to optimize human resources allocation based on spatial diversity of COVID-19 cases in Poland. EMethodol. 2021; accepted.

13. Jarynowski A, Wójta-Kempa, Monika. Zróżnicowanie geograficzne szczepień p/COVID19 w Polsce - nierówności społeczne i peryferyjność, a możliwe środki zaradcze [Internet]. 2021. Available from: https://www.academia.edu/50340205/Zróżnicowanie_geograficzne_szczepień_p_COVI D_19_w_Polsce_nierówności_społeczne_i_peryferyjność_a_możliwe_środki_zaradcze

14. European Covid-19 Forecast Hub. Forecasts · Cases, Poland (June-September 2021) [Internet]. 2021. Available from: https://covid19forecasthub.eu/visualisation.html?fbclid=IwAR1dT9Qqb6nK9JLVipZsy6z qyrVg6LTPR5ndnTgi-xDUSB1rSzXg2eNk2So

15. Subramanian SV, Kumar A. Increases in COVID-19 are unrelated to levels of vaccination across 68 countries and 2947 counties in the United States. Eur J Epidemiol [Internet]. 2021 Sep 30; Available from: https://link.springer.com/10.1007/s10654-021-00808-7

16. Rogalski M. COVID-19 wedlug powiatow [Internet]. 2020. Available from: https://docs.google.com/spreadsheets/d/1Tv6jKMUYdK6ws6SxxAsHVxZbglZfisC8x_H Z1jacmBM/edit?usp=sharing

17. GUS. Bank danych lokalnych [Internet]. 2020. Available from: https://bdl.stat.gov.pl/BDL/start

18. MZ. Szczepienia gmin [Internet]. 2021. Available from: https://www.gov.pl/web/szczepienia-gmin

19. MZ. Statystyki zgonów z powodu COVID-19 [Internet]. 2021. (Baza Analiz Systemowych i Wdrożeniowych). Available from: https://basiw.mz.gov.pl/index.html\#/visualization?id=3653 
medRxiv preprint doi: https://doi.org/10.1101/2021.12.08.21267167; this version posted December 9,2021 . The copyright holder for this

preprint (which was not certified by peer review) is the author/funder, who has granted medRxiv a license to display the preprint in perpetuity.

All rights reserved. No reuse allowed without permission.

20. RCB. Raport dobowy COVID-19 [Internet]. 2021. Available from: https://www.gov.pl/web/rcb/raport-dobowy-covid-19

21. PZH-NIZP. Ogólnopolskie Badanie Seroepidemiologiczne COVID-19 - OBSER-CO: raport z I tury badania [Internet]. 2021. Available from: https://www.pzh.gov.pl/projektyi-programy/obserco/raporty/

22. ECDC. COVID-19 surveillance guidance. [Internet]. 2021 Available from: https://www.ecdc.europa.eu/en/publications-data/covid-19-surveillance-guidance

23. WHO. Guidance for surveillance of SARS-CoV-2 variants: interim guidance. [Internet]. 2021 Available from: https://www.who.int/publications/i/item/WHO_2019nCoV_surveillance_variants

24. Meslé MM, Brown J, Mook P, Hagan J, Pastore R, Bundle N, Spiteri G, Ravasi G, Nicolay N, Andrews N, Dykhanovska T. Estimated number of deaths directly averted in people 60 years and older as a result of COVID-19 vaccination in the WHO European Region, December 2020 to November 2021. Eurosurveillance. 2021 Nov 25;26(47):2101021.

25. Bochenek B, Jankowski M, Gruszczynska M, Jaczewski A, Ziemianski M, Pyrc R, Wyszogrodzki A, Nykiel G, Kopaczka D, Figurski M, Pinkas J. Weather as a potential cause of regional differences in the dynamics of the COVID-19 epidemic in Polandimplications for epidemic forecasting. Polish Archives of Internal Medicine. 2021 Oct 8.

26. Szmuda T, Ali S, Özdemir C, Syed MT, Singh A, Hetzger TV, et al. Datasets and future research suggestions concerning the novel Coronavirus (COVID-19). Eur J Transl Clin Med. 2020 Dec 3;3(2):80-5. 